\title{
Ante-mortem analysis, electrical, thermal, and ageing testing of state-of-the-art cylindrical lithium-ion cells
}

\author{
H. Popp (D, N. Zhang, M. Jahn, M. Arrinda, S. Ritz, M. Faber, D. U. Sauer, P. Azais, I. Cendoya
}

\begin{abstract}
Thanks to its exceptional performance in terms of high energy and power density as well as long lifespan, the lithium-ion secondary battery is the most relevant electrochemical energy storage technology to meet the requirements for partial or full electrification of vehicles (plug-in hybrids or pure electric vehicles), and thanks to decreasing cost and ongoing technical improvements, it will maintain this role in the near to mid-term future. This study benchmarks eight different (five 21700 and three 18650 format) high-energy cylindrical cells concerning their suitability for automotive applications and aims to give a holistic overview and comparison between them. Therefore, an ante-mortem material analysis, a benchmark of electrical and thermal values as well as a cycle life study were carried out. The results show that even when applying similar concepts like Nickel-rich cathodes with graphite-based anodes, the cells show wide variations in their performance under the same test conditions.
\end{abstract}

Keywords: lithium-ion battery; electric vehicles; benchmark; material analysis; ageing; electrical performance; thermal performance

\section{Ante-Mortem-Analyse sowie elektrische, thermische und Alterungstests von State-of-the-Art zylindrischen Lithium-Ionen-Zellen.}

\begin{abstract}
Aufgrund ihrer hervorragenden Eigenschaften in Bezug auf Energie- und Leistungsdichte sowie ihrer hohen Lebensdauer ist die Lithium-Ionen-Sekundärbatterie der bevorzugte elektrochemische Energiespeicher zur teilweisen oder vollständigen Elektrifizierung von Fahrzeugen (Plug-In-Hybride oder reine Elektrofahrzeuge). Dank sinkender Kosten und laufenden technischen Verbesserungen wird die Li-lonen Batterie diese Rolle auch in naher bis mittelfristiger Zukunft beibehalten. Diese Studie bewertet acht verschiedene (fünf 21700 und drei 18650-Format) zylindrische Zellen mit hoher Energiedichte hinsichtlich ihrer Eignung für Automobilanwendungen, um einen ganzheitlichen Überblick und Vergleich zwischen den Zellen zu geben. Zu diesem Zweck wurden eine zerstörende Materialanalyse, ein Benchmark der elektrischen und thermischen Werte sowie ein Test zur Ermittlung der Zyklenlebensdauer durchgeführt. Die Ergebnisse zeigen, dass selbst bei Anwendung ähnlicher Materialkonzepte, wie Kathoden mit sehr hohem Nickel-Anteil und mit Anoden auf Graphitbasis, die jeweiligen Zelltypen unter den gleichen Testbedingungen große Unterschiede in Einzel- und Gesamtperformance aufweisen.
\end{abstract}

Schlüsselwörter: Lithium-lonen-Sekundärbatterie; Elektrofahrzeuge; Vergleichstest; Materialanalyse; Alterung; elektrische Performance; thermische Performance

Received April 23, 2020, accepted June 5, 2020, published online June 16, 2020

(c) The Author(s) 2020

\section{Introduction}

The climate and energy framework for the year 2030 set by the European Commission [1] demands at least

- $40 \%$ cuts in greenhouse gas emissions,

- $32 \%$ share for renewable energy, and

- $32.5 \%$ improvement in energy efficiency;

all compared to the levels of the year 1990. Especially for road transport these goals are ambitious, since by 2017, emissions increased by $23 \%$ compared to 1990 [2]. Electrification of the transport sector is seen as a key solution to reduce the environmental impact of road transport. The lithium-ion secondary (also known as rechargeable) battery (LIB) is now playing and is believed to continue to play a major role in this scenario in the mid-term. A global market of at least 44 million battery electric vehicles (EV) for the year 2030 is prognosticated, not including two-wheelers and micro transport [3].

Cylindrical LIB cells have a competitive edge when it comes to traction batteries because they offer high intrinsic safety and flexibility in battery system design, all at reasonable cost [4]. Additionally, some of the highest energy densities of cells currently available on the market can be found in this format. Therefore, they are used in

Popp, Hartmut, AIT Austrian Institute of Technology, Center for Low-Emission Transport, 1210 Vienna, Austria (E-mail: hartmut.popp@ait.ac.at); Zhang, Ningxin, AIT Austrian Institute of Technology, Center for Low-Emission Transport, 1210 Vienna, Austria; Jahn, Marcus, AIT Austrian Institute of Technology, Center for Low-Emission Transport, 1210 Vienna, Austria; Arrinda, Mikel, CIDETEC, Energy Storage Systems Unit, 20014 Donostia-San Sebastián, Spain; Ritz, Simon, Chair for Electrochemical Energy Conversion and Storage Systems, Institute for Power Electronics and Electrical Drives (ISEA), RWTH Aachen University, 52056 Aachen, Germany und Jülich Aachen Research Alliance, JARA-Energy, 52056 Aachen, Germany; Faber, Matthias, Chair for Electrochemical Energy Conversion and Storage Systems, Institute for Power Electronics and Electrical Drives (ISEA), RWTH Aachen University, 52056 Aachen, Germany und Jülich Aachen Research Alliance, JARA-Energy, 52056 Aachen, Germany; Sauer, Dirk Uwe, Chair for Electrochemical Energy Conversion and Storage Systems, Institute for Power Electronics and Electrical Drives (ISEA), RWTH Aachen University, 52056 Aachen, Germany und Jülich Aachen Research Alliance, JARA-Energy, 52056 Aachen, Germany; Azais, Philippe, Université Grenoble Alpes, CEA, LITEN, DEHT, F-38000 Grenoble, France; Cendoya, Iosu, CIDETEC, Energy Storage Systems Unit, 20014 Donostia-San Sebastián, Spain 
Table 1. Manufacturer and model, energy density according to datasheet, and country of origin of tested cells

\begin{tabular}{lll}
\hline Manufacturer and model & Energy density in Wh/kg & Country \\
\hline LG INR18650-MJ1 & 259.6 & Korea \\
PANASONIC NCR18650-B & 248.7 & Japan \\
SAMSUNG INR18650-35E & 252.0 & Korea \\
LG INR21700-M50 & 263.0 & Korea \\
SAMSUNG INR21700-48G & 250.4 & Korea \\
SAMSUNG INR21700-50E & 260.9 & Korea \\
SONY 21700-50EL & 257.0 & Japan \\
SONY 21700-52EM & 267.4 & Japan \\
\hline
\end{tabular}

micro-mobility, motorcycles [5] and cars [6]. Nowadays, these cells are mostly produced in 18650 and 21700 formats.

Despite the popularity of these cells for such applications, a holistic review of state-of-the-art cells for automotive applications is not available. The collaborative Horizon2020 research project iModBatt [7], among other goals, aims to fill this gap. This work presents a selection of the interesting results which were achieved and focuses on the materials used, electrical and thermal benchmarks, as well as the cyclic aging behavior. In February 2018 a market survey on small cylindrical LIB cells was carried out in order to find commercially available high-energy cells, based on which a selection of five 21700 and three 18650 format cells was chosen. This panel includes the best energy densities of batteries available on the market from major suppliers which in this case are LG Chem, Panasonic, Samsung, and Sony/Murata. The energy density ranges from 248.7 $\mathrm{Wh} / \mathrm{kg}$ up to $267.4 \mathrm{Wh} / \mathrm{kg}$. The evaluation was done with automotive specifications for passenger cars with pure electric drive.

\section{Experimental}

Table 1 provides an overview of the selected cells; their manufacturer, model, gravimetric energy density according to datasheets, as well as the country of origin are given. The goal of the study was to check these cells for their ability to work under automotive operational conditions for an EV setup, including space restrictions and performance values, as predefined by two OEM companies. For this reason, some cells were tested with current and power values out of their operational window. The authors are aware that this can negatively impact the performance of individual cells but decided for this procedure for the sake of comparability.

Cells were scanned for material availability and environmental impact, electrical and thermal performance and lifetime; so destructive material analysis, electro- and thermal benchmark and cycle life tests were carried out and are described below.

For each type of cell, a destructive ante-mortem analysis was carried out to better identify the active materials used (types and quantities) and to identify the presence of coatings. Materials and their morphology were examined using a scanning electron microscope (SEM) ESEM XL40 (FEI, US) equipped with energy-dispersive X-ray spectroscopy (EDX) and a second SEM type Supra 40 (Carl Zeiss AG, Germany), equipped with wavelength dispersive $X$-ray spectrometry (WD-XRF) and X-ray crystallography (XRD). For the analysis, cells were fully discharged and disassembled in an Argon-filled $(<0.1 \mathrm{ppm}$ of $\mathrm{O}_{2}$ and $\mathrm{H}_{2} \mathrm{O}$ ) glove box (MBraun, Germany). Representative sample pieces of each electrode were collected from the disassembled cells under inert atmosphere and washed using a dimethyl carbonate (DMC) solution to remove residual salts from the electrolyte. The microstructure and elements were analyzed in areas of interest by EDX at least two times to guarantee repeatability.
For electrochemical cell characterization, three samples per type were analyzed. The test specifications are based on the standard IEC 62660-1 [8] to achieve comparable results, which also can serve as benchmarks for other projects. Discharge capacity was measured three times at $10{ }^{\circ} \mathrm{C}, 25^{\circ} \mathrm{C}$ and $45^{\circ} \mathrm{C}$, for two current-rates (Crates) of $0.05 \mathrm{C}$ and $0.5 \mathrm{C}$ in a climatic chamber. The value of the last full discharge from a fully charged state down to $2.5 \mathrm{~V}$ for all cells was taken as a basis for further analysis and comparison in this study. In between a standard charge with the nominal current of $1 \mathrm{C}$ constant current (CC) and $\mathrm{V}_{\text {MAX }}$ set to $4.2 \mathrm{~V}$, constant voltage (CV) with termination criterion of $\mathrm{I} \leq \mathrm{C} / 20$ (CV @ C/20) was performed. Resistance tests were applied at a state-of-charge (SOC) of $50 \%$, at $10^{\circ} \mathrm{C}, 25^{\circ} \mathrm{C}$, and $45^{\circ} \mathrm{C}$ and by applying pulses with three $\mathrm{C}$-rates of $0.5 \mathrm{C}, 1 \mathrm{C}$, and $2 \mathrm{C}$ with a break for relaxation in between. The duration of each pulse was $60 \mathrm{~s}$; the ohmic drop was determined after $0.5 \mathrm{~s}$ during a discharge pulse.

Since heat generation during cycling is an essential parameter in the design of a battery system and the selection of a suitable cooling concept, many calorimetric measurement series were carried out during the benchmarking tests. In particular, the aim was to evaluate the heat generation rate (HGR) during discharge. Since the HGR depends on both the cell temperature and the applied current rate, the measurement was repeated for each of the five 21700 type cells ${ }^{1}$ investigated at $20^{\circ} \mathrm{C}, 35^{\circ} \mathrm{C}$, and $50^{\circ} \mathrm{C}$, and again for three $\mathrm{C}$-rates i.e. $0.2 \mathrm{C}, 0.5 \mathrm{C}$, and $1.0 \mathrm{C}$. It should be noted that in order to compare the results of different cells and their use in the battery pack design process, it is important to perform the tests at C-rates related to the cell capacity and not at a constant reference current. Only this way results independent of the absolute value of the cell capacity can be obtained.

The measurements were carried out in an isothermal battery testing calorimeter of the type isoBTC (H.E.L. Group, UK) which works according to the power compensation principle. This means that the average surface temperature of the sample was actively controlled to the temperature setpoint with a precision of a few tens of millikelvins utilizing a closed-loop control system. The efficiency of the control loop was calibrated in a preliminary test. The total heat output of the sample is calculated from the change in the manipulated variable of the control loop.

For the aging tests, all different cell types with eight samples per type were cycled at room temperature $\left(25^{\circ} \mathrm{C}\right)$ with different $\mathrm{CC}$ rates and different depth-of-discharge (DOD), according to a statistically optimized cycling regime (see [9]). Additionally, two cells per type were cycled with a downscaled real-life profile from two different OEMs (details on cycles see [10] available on [7]). Table 2 provides the number of cells, DOD, and the charge-discharge settings; with PP for power profile and CP for constant power. The average SOC is $50 \%$ for all cells. The voltages $V_{\text {MIN }}$ and $V_{\text {MAX }}$ were defined with $2.5 \mathrm{~V}$ and $4.2 \mathrm{~V}$ respectively, to have homogenous testing conditions, and are within the values of all types of cells according to their datasheet. The other values were derived from quasi-static open-circuit voltage (OCV) tests, meaning a discharge with very low current, where OCV almost equals $V_{\text {CELL. }}$

Cycling was performed for 6 months or until the remaining capacity was less than $80 \%$ of initial capacity or operational temperature became too high - whichever occurred first. Regular checkups at every 75 full equivalent cycles provided full-cycle datasets enabling comparison of cell types and load profile impacts.

\footnotetext{
${ }^{1}$ Due to hardware availability, only the 21700 cells were investigated during thermal testing.
} 
Table 2. Number of tested cells per type DOD and charge/discharge settings

\begin{tabular}{|c|c|c|c|}
\hline \# & DOD in \% & Charge settings & Discharge settings \\
\hline 1 & 100 & 1 C CC, V $\operatorname{MAX}$ CV@C/20 & 1 C CC, V VIN CV@C/20 \\
\hline 3 & 80 & 1 C CC, 4.055 V CV@C/20 & 1 C CC, 3.210 V CV@C/20 \\
\hline 1 & 60 & 1 C CC, 3.980 V CV@C/20 & 1 C CC, 3.421 V CV@C/20 \\
\hline 1 & 80 & 0.5 C CC, 4.055 V CV@C/20 & 1 C CC, 3.210 V CV@C/20 \\
\hline 1 & 100 & 1 C CP, Vmax CV@C/20 & OEM1 [10], PP to $\mathrm{V}_{\mathrm{MIN}}$ \\
\hline 1 & 80 & 1 C CP, Vmax CV@C/20 & OEM2 [10], PP to $3.210 \mathrm{~V}$ \\
\hline
\end{tabular}

\section{Results}

The results shown in the following subsections aim to give an overview and permit for comparison of the different cell types and used material compositions.

\subsection{Ante-Mortem analysis}

Figure 1 (a) shows the typical microstructural SEM image of Nickelrich (Ni-rich) Lithium-Nickel-Manganese-Cobalt (NMC) cathodes and Fig. 1 (b) one of the graphite (G) anodes of SAM INR18650-35E after forming but without further cycling. The image shows that for cathodes, a compound approach was taken for the conductive additive for optimized power and energy balance. Here, nanosized carbon black (CB) (labeled by dotted blue circles in Fig. 1 (a)) suitable for spot conduction and typically used for higher energy densities was combined with vapor grown carbon fibers (VGCF) (labeled by red arrows in Fig. 1 (a)). These are good for connecting spot conduction paths and therefore enable better conductive networks within the electrode, which is especially required for higher C-rate applications [11]. In (b), the surface of graphite after several electrochemical cycles is shown, where the solid electrolyte interface (SEI) related surface structure was found. Graphite platelets were found in all cases, meaning natural or flakey graphite was used as the main anode active component. This usually allows a dense packing structure during calendering (pressing of the active material layer on the current collector) of the anodes and therefore enables high energy densities.

Figure 2 shows the results of anode EDX measurement for the example of SAM INR18650-35E. The active material mainly consists of carbon, but Silicon (Si) based materials were also detected. This composition was also found in other cells we investigated (Table 3). Si usually is added to increase the capacity of the anode as its specific capacity (4200 $\mathrm{mA} \mathrm{h} \mathrm{g}^{-1}$ ) is more than ten times higher than that of graphite (372 $\mathrm{mA} \mathrm{h} \mathrm{g}^{-1}$ ). As $\mathrm{Si}$ is prone to considerable changes in volume during lithiation (around $360 \%$ ) compared to graphite (around $10 \%$ ), it causes increased structural disintegration of the cell during cycling and has a negative impact on cycle life [12]. For this reason, the content of $\mathrm{Si}$ is kept around only $1 \% \mathrm{wt}$ in all cells, which reflects a tradeoff between increase in capacity and decrease of cycle life. The trace of fluorine (F) and phosphorus (P) elements most likely results from the residuals of electrolyte during the preparation of electrode samples.

The analytical results of EDX have been confirmed by XRF analysis (not shown here) and thus allows to define the electrochemical system of the cells. Table 3 shows a summary of the analysis. On the cathode, Lithium-Nickel-Cobalt-Manganese (NCM) 811 was adopted for LG and Lithium-Nickel-Cobalt-Aluminum (NCA) for cells by PAN and SAM, respectively. On the anode, flakey type natural graphite was used for all cells, with selected ones containing traces of Si. Present trend in the automotive sector, is to use artificial graphite as it enables higher lifetime [13]. This may be the reason for observing low cycle lifespan for the cells tested, however this

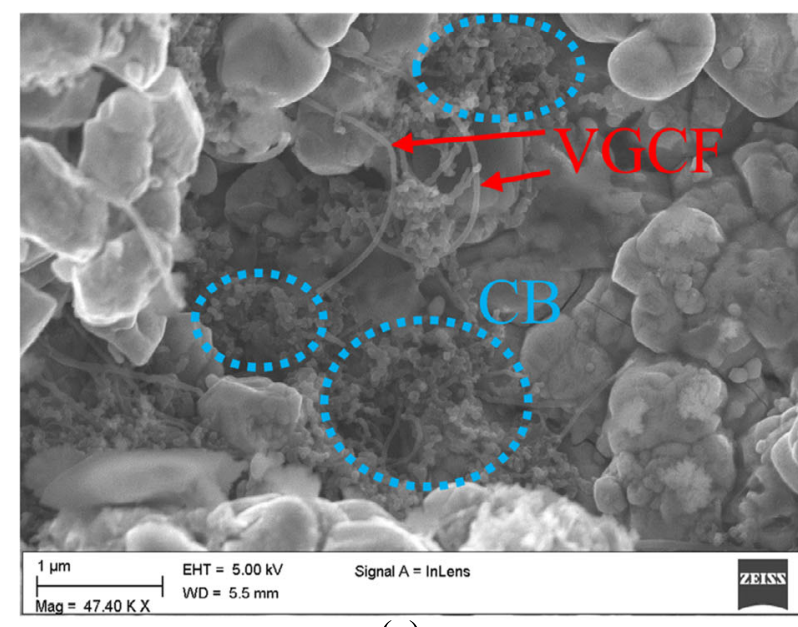

(a)

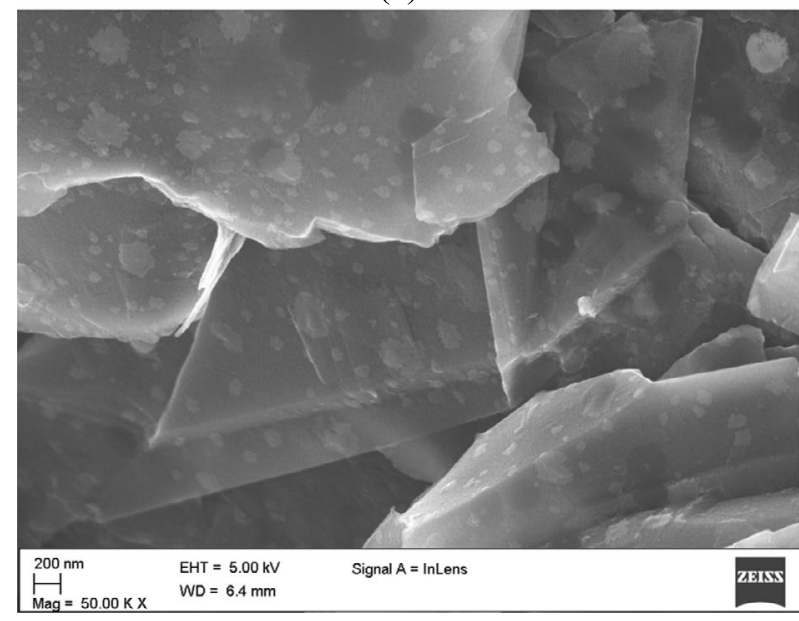

(b)

Fig. 1. SEM image of cathode (a) and anode (b) of SAM INR18650-35E

should not explain such an indeed short cycle life for some of the cells. Based on the choice of active materials as well as the physical properties of the analyzed electrodes, these cells indeed have been optimized for high energy density applications.

\subsection{Electrical benchmark}

Figure 3 (a) shows results for the measured cell capacities while Fig. 3 (b) shows the one for ohmic resistances for all types of cells for the applied current and temperatures.

In general, the net amount of discharged capacity is expected to decrease at lower cell temperatures and to increase at higher cell temperatures. The results show that the lowest dischargeable capacity values are obtained at $10^{\circ} \mathrm{C}$; and that the highest dischargeable 


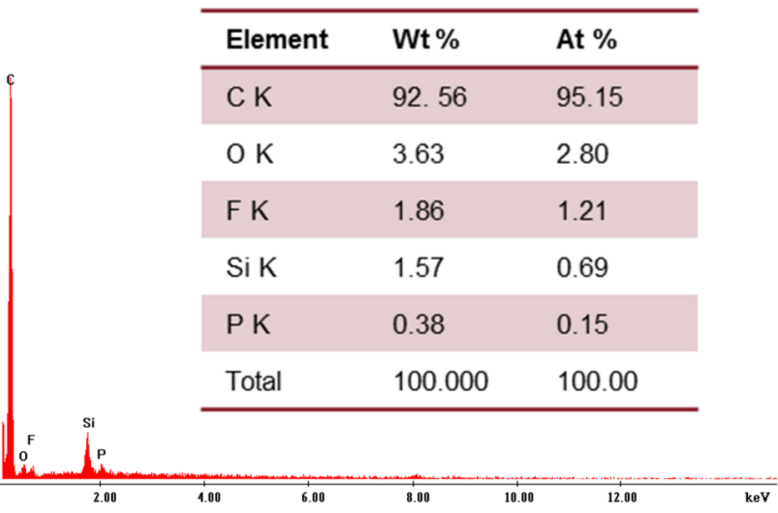

Fig. 2. EDX analysis of SAM INR18650-35E anode

Table 3. Material composition of the electrodes according to antemortem analysis

\begin{tabular}{lll}
\hline Model & Anode & Cathode \\
\hline INR18650-MJ1 & Graphite + 1\%wt Si & $\mathrm{Li}\left(\mathrm{Ni}_{0.84} \mathrm{Co}_{0.11} \mathrm{Mn}_{0.05}\right) \mathrm{O}_{2}$ \\
NCR18650-B & Graphite & $\mathrm{Li}\left(\mathrm{Ni}_{0.88} \mathrm{Co}_{0.11} \mathrm{Al}_{0.01}\right) \mathrm{O}_{2}$ \\
INR18650-35E & Graphite + 1\%wt Si & $\mathrm{Li}\left(\mathrm{Ni}_{0.87} \mathrm{Co}_{0.11} \mathrm{Al}_{0.02}\right) \mathrm{O}_{2}$ \\
INR21700-M50 & Graphite + 1\%wt Si & $\mathrm{Li}\left(\mathrm{Ni}_{0.84} \mathrm{Co}_{0.10} \mathrm{Mnn}_{0.06}\right)_{2}$ \\
INR21700-48G & Graphite + 1\%wt Si & $\mathrm{Li}\left(\mathrm{Ni}_{0.80} \mathrm{Co}_{0.15} \mathrm{Al}_{0.05}\right) \mathrm{O}_{2}$ \\
INR21700-50E & Graphite + 1\%wt Si & $\mathrm{Li}\left(\mathrm{Ni}_{0.80} \mathrm{Co}_{0.15} \mathrm{Al}_{0.05}\right) \mathrm{O}_{2}$ \\
21700-50EL & Graphite & $\mathrm{Li}\left(\mathrm{Ni}_{0.84} \mathrm{Co}_{0.10} \mathrm{Mn}_{0.06}\right) \mathrm{O}_{2}$ \\
21700-52EM & Graphite & $\mathrm{Li}\left(\mathrm{Ni}_{0.80} \mathrm{Co}_{0.15} \mathrm{Al}_{0.05}\right) \mathrm{O}_{2}$ \\
\hline
\end{tabular}

capacity values are obtained at $45^{\circ} \mathrm{C}$, except for SON 21700-52EM, where the highest dischargeable capacity values are obtained at 25 ${ }^{\circ} \mathrm{C}$ on all three samples tested for this condition. This means that this battery is sensitive to both low and high temperatures and that its optimized for an operation temperature of $25^{\circ} \mathrm{C}$, possibly with additives in the electrolyte. In addition, this battery is the only one that does not reach the rated capacity even for low C-rates. The minimum capacity is $5 \mathrm{Ah}$ and the nominal one is $5.2 \mathrm{Ah}$ according to the datasheet of the cell, while during testing a maximum of 4.9 Ah was reached. The reason for this is most likely the narrow voltage operation window of $2.5 \mathrm{~V}$ to $4.2 \mathrm{~V}$ which was chosen for all cells to keep results comparable, while this cell was the only one that could work from $2 \mathrm{~V}$ to $4.25 \mathrm{~V}$. Applying this extra voltage window, the cell is likely to close this gap of 0.3 Ah between datasheet and achieved values.

The results also show that the net amount of discharged capacity decreases at higher C-rates and increases at lower C-rates, as was expected. Some exceptions where the dischargeable capacity is slightly higher at $0.5 \mathrm{C}$ than at $1 \mathrm{C}$ were found, but the difference is lower than $0.1 \%$, and thus within the measurement uncertainty of the test bench. The lowest dispersion of the capacity measurements is observed for LG INR18650-MJ1, followed by SON 21700-50EL.

The pure ohmic resistance calculations illustrated in Fig. 3 (b) show that resistance in general becomes lower for higher temperatures, with the exception of SON 21700-50EL, which shows lower resistance at $10^{\circ} \mathrm{C}$ than at $25^{\circ} \mathrm{C}$. In general, the SON 21700-50EL shows the lowest resistance at $10^{\circ} \mathrm{C}$ of all cells tested, while that of LG INR21700-M50 has the highest one at this temperature, showing an increase of $400 \%$ compared to the resistance values measured at $45^{\circ} \mathrm{C}$. Thus, while providing competitive performance at higher temperatures, the LG INR21700-M50 is not the best choice for low temperature applications.

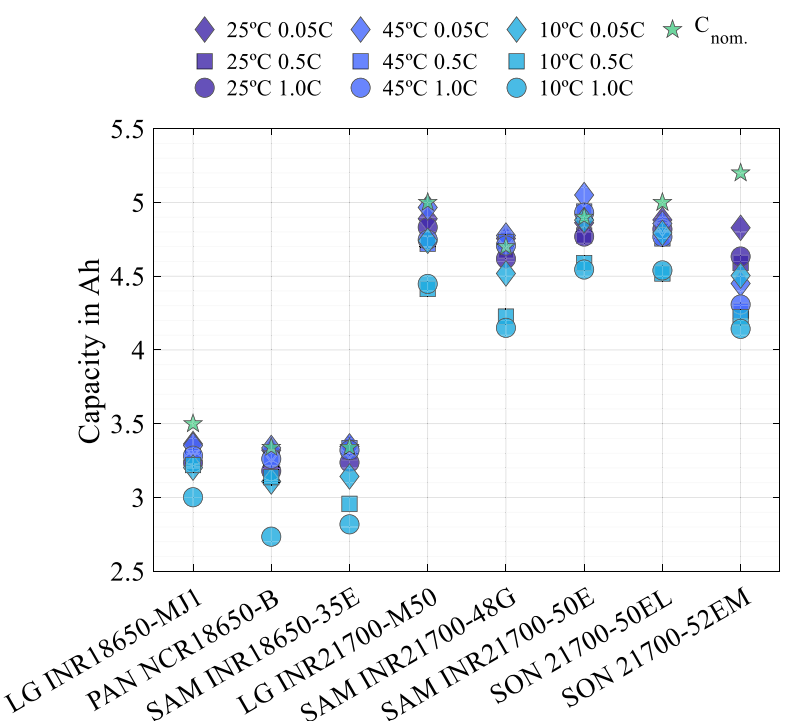

(a)

$25^{\circ} \mathrm{C} 0.5 \mathrm{C} \diamond 45^{\circ} \mathrm{C} 0.5 \mathrm{C} \diamond 10^{\circ} \mathrm{C} 0.5 \mathrm{C}$ $25^{\circ} \mathrm{C} 1.0 \mathrm{C} \square 45^{\circ} \mathrm{C} 1.0 \mathrm{C} \square 10^{\circ} \mathrm{C} 1.0 \mathrm{C}$ $25^{\circ} \mathrm{C} 2.0 \mathrm{C} \bigcirc 45^{\circ} \mathrm{C} 2.0 \mathrm{C} \bigcirc 10^{\circ} \mathrm{C} 2.0 \mathrm{C}$

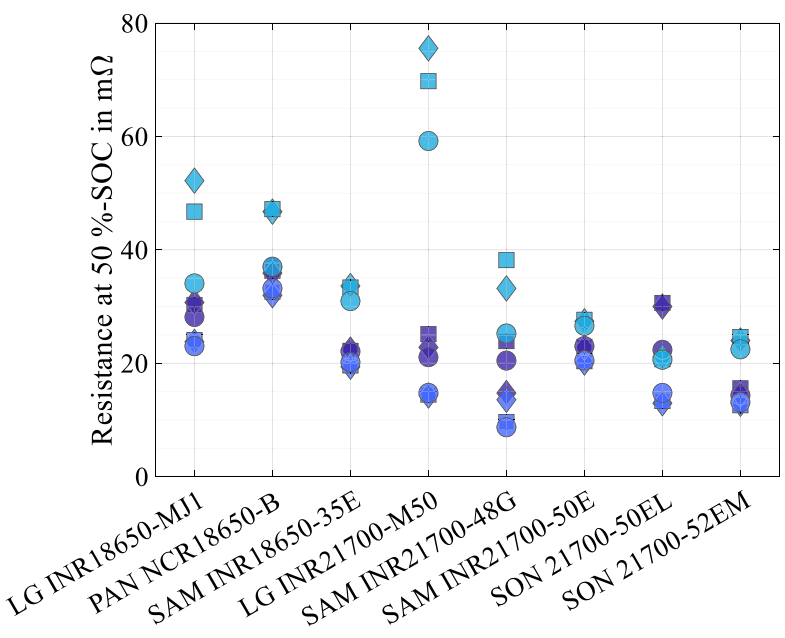

(b)

Fig. 3. Map of capacity (a) and resistance (b)

Among all the samples, SAM INR21700-50E exhibits the lowest resistance dispersion due to temperature and $\mathrm{C}$-rate, indicating that this cell has the most stable resistive performance for the temperature and C-rate operation range tested. SAM INR21700-48G, on the other hand, exhibits the lowest minimum resistance value, but also a dispersion of nearly $400 \%$ among the different conditions tested, suggesting that its resistive performance will be determined by the operation conditions. Overall, among the tested batteries, the SAM INR21700-50E can deliver a $3 \%$ higher capacity at $45^{\circ} \mathrm{C}$ than the nominal value, and it has the lowest resistance dispersion. This ranks the electric performance of SAM INR21700-50E above the rest of the tested cells.

\subsection{Thermal benchmark}

From the data in Table 1 it is evident that all the cells have a similar cell design trimmed for very high energy density. Focusing on the 21700-type cells, the results of the electrical benchmark in Fig. 3 a) and b) also show that the capacities and inner resistances of these 


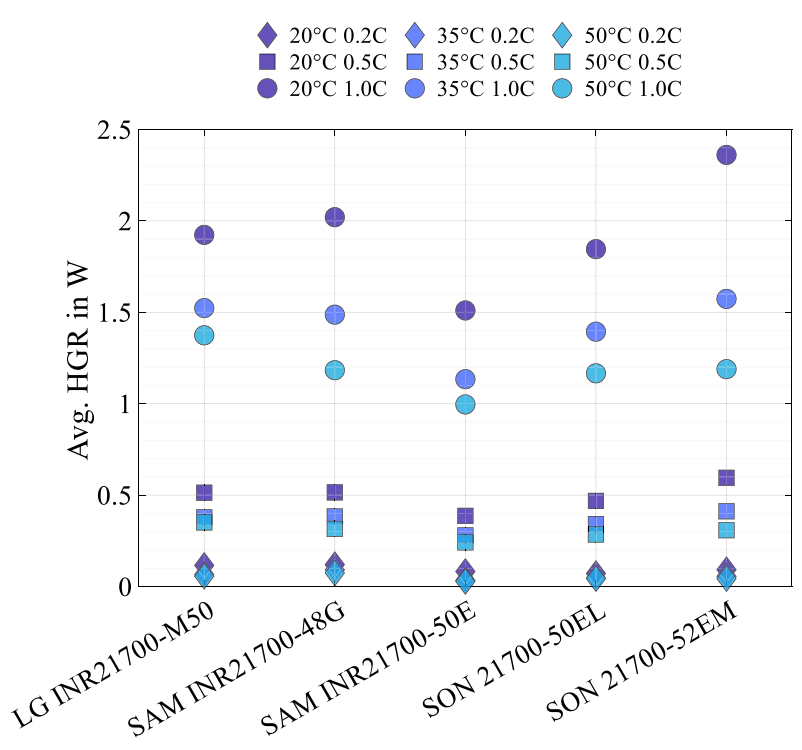

Fig. 4. Average HGR for all 21700 type cells at various C-rates and temperature levels

cells only differ by a few per cent. Taken together, this can be an indicator for a similar overall design concerning their power to energy ratio and thus an overall similar heat generation behavior, which can also be confirmed by the results of the isothermal calorimetry (Fig. 4). However, especially in the measurements at lower temperatures and higher current rates, namely at $20^{\circ} \mathrm{C}$ and $1.0^{\circ} \mathrm{C}$, considerable differences in the measured heat generation rates were observed as well. The HGR of the best performing cell, i.e. SAM INR21700-50E is about $1.5 \mathrm{~W}$ on average while the SON 2170052EM type cell has an average HGR of about $2.4 \mathrm{~W}$.

For more straightforward comparability of the thermal loss characteristics of the chemistries and designs used, the quotient of the thermal losses $\zeta_{\text {loss, }}$ defined as

$$
\zeta_{\text {loss }}=\frac{\dot{Q}}{P_{\mathrm{el}}}
$$

is plotted in Fig. 5 (a), in addition to the direct plot of the HGR. $\dot{Q}$ is the heat flow in Watt $(\mathrm{W})$ and $P_{\mathrm{el}}$. is the electrical power in $\mathrm{W}$. The integral of the HGR over the entire discharge process is shown in Fig. 5 (b) which makes it possible to estimate the cooling requirement during operation to keep the battery cells within a safe thermal operating window, considering their thermal capacities.

In the application of the battery cells in an EV with a pack level energy of about $40 \mathrm{kWh}$, a constant discharge at $0.5 \mathrm{C}$ on average roughly corresponds to a motorway trip. The heat amounts to $2 \mathrm{~kJ}$ to $4 \mathrm{~kJ}$ per cell at a heat capacity of approximately $70 \mathrm{~J} / \mathrm{K}$, which is derived from the calorimetric measurements, making it clear that an effective cooling system is necessary to ensure the desired thermal operating window permanently.

Because the SAM INR21700-50E type cell performed consistently better than its competitors during the thermal tests, the calorimetric tests result in an advantage for the SAM INR21700-50E.

\subsection{Cyclic ageing}

Figure 6 shows the number of equivalent full cycles calculated as full cycles $=Q_{\text {discharge }} / C_{\text {nominal }}$ for all cells at various charge- and discharge settings (Table 2). The markers indicate the number of cycles achieved before $C_{a c t u a l} \leq 0.8 \cdot C_{\text {initial; }}$; the values were inter- or extrapolated linearly over all data points to get the intersection. For details

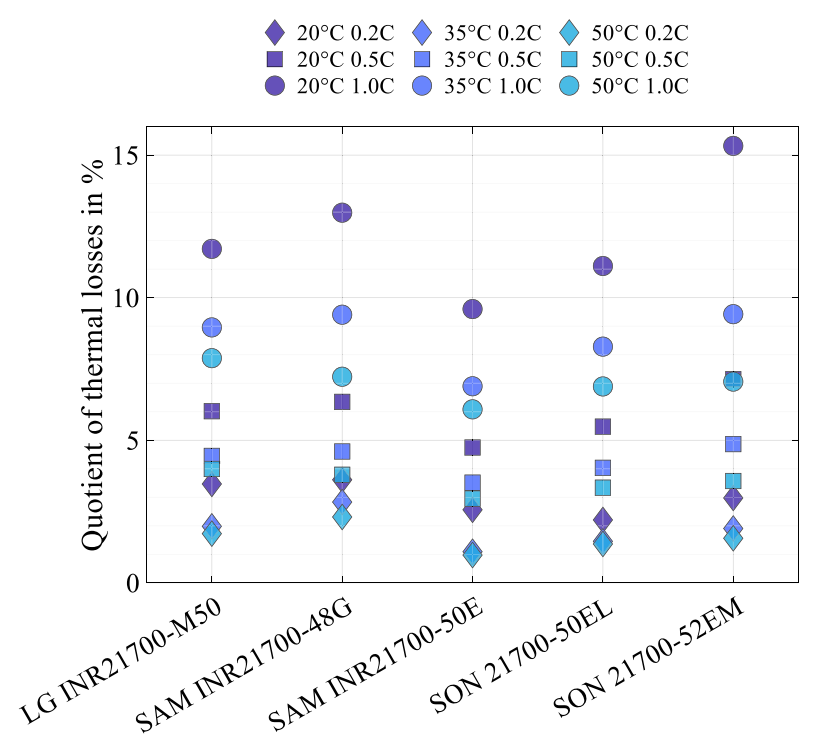

(a)

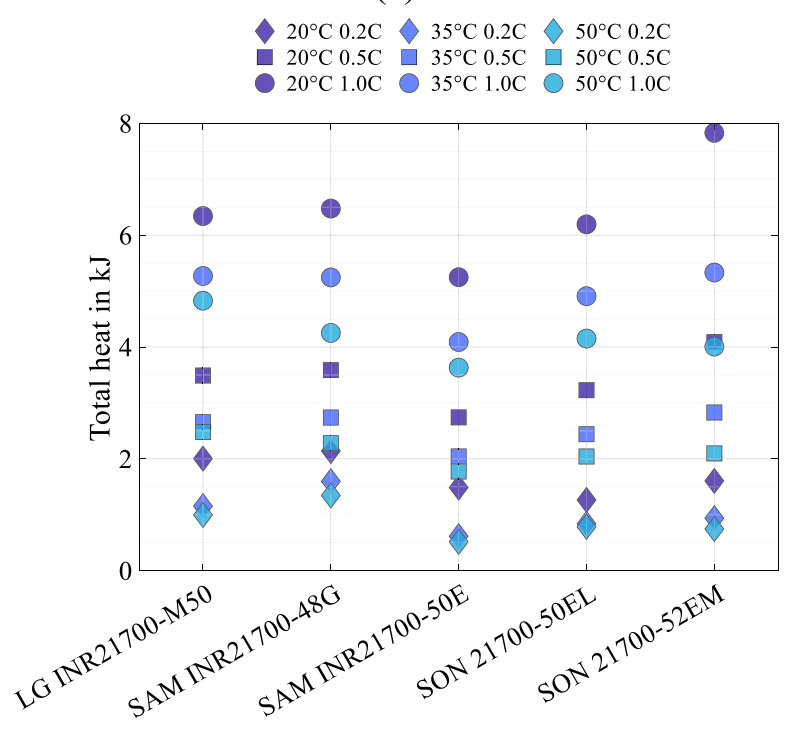

(b)

Fig. 5. Sloss (a) and integral of HGR (b) for all 21700 type cells at various $\mathrm{C}$-rates and temperatures

on cycling results see [14], available on [7], where the capacity development for each cell during cycle life testing is presented. No indication of cycles means that such cells did not make it to the first checkup test without failing at least one of the termination or safety criteria. There is a huge variation in results even among cells coming from the same manufacturers, e.g., SAM provided both the weakest and the best cells tested. This is likely to mainly arise from the challenging demands of the automotive scenario that was applied to the cells. For example, the SAM INR21700-48G cell has a recommended charging current of $0.33 \mathrm{C}$, but like all the other cells it was tested at least with a $0.5 \mathrm{C}$ charging current and most of the times higher at $1 \mathrm{C}$ or even up to $1.48 \mathrm{C}$ for the OEM1 profile. The same is true for the discharge rate of the OEM2 profile, which exceeds $2 \mathrm{C}$ and therefore does not comply with the data sheet values of all the cells tested. Consequently, the results provided must be seen in relation to the harsh testing regime that was not suited to all types of cells tested. In general, as expected, all cells performed best for lower 


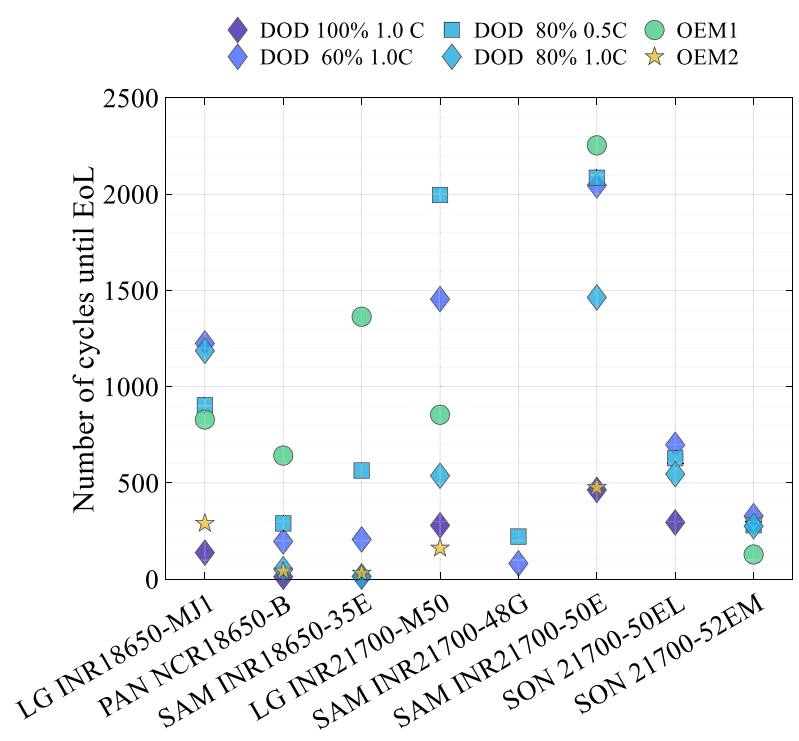

Fig. 6. Comparison of cycle life with different operating windows for all cell types

charging rates and lower DOD windows. The SAM INR21700-50E, despite being a high energy cell with a recommended charging rate of $0.5 \mathrm{C}$, provides high cycle life for high charging and discharging rates of the OEM1 and OEM2 profile. For DOD $60 \% 1 C$ and DOD $80 \% 0.5 \mathrm{C}$ more than 200 equivalent full cycles are achieved which is enough under such conditions for automotive purposes [15]. As seen with all the other cells too, full cycles (DOD $100 \%$ ) with 1 C lead to degradation most quickly.

\section{Summary and discussion}

Table 1 showed that all the cells with the highest energy densities available on the market originate from just two Asian countries and four manufacturers. Energy densities are almost consistent among manufacturers and cell sizes.

Ante-mortem material analysis (Table 3) showed, that the trend is clearly towards Ni-rich systems (Ni-rich NCM and NCA) for the cathode. This approach is beneficial in terms of cost and sourcing of materials, as cobalt is costly, originating from fewer countries and is known as being critically in terms of mining conditions [16]. Weak conductivity in this high-energy material is reduced by adding both $C B$ and small amounts of VGCF (as it is much more expensive than CB). On the anode side $G$ is still the sole choice. For further improvement of the capacity small amounts of $\mathrm{Si}$ are added to five of the eight cell types analyzed. Regarding the 'classic' 18650 and the 'new' 21700 formats, no trend for the used materials was observed. This is in line with the test results, where no superior format is discernible.

In terms of the electrical benchmark, the 18650 type cells, in general, show less total capacity and higher total resistance (Fig. 3) as they consist of less material in total. When referring to the weight of the cells, it appears that 18650 type cells exhibit less resistance and less capacity than 21700 type cells, e.g. the SAM INR18650-35E has $1109 \mathrm{~m} \Omega \cdot \mathrm{g}$ and $64.7 \mathrm{mAh} / \mathrm{g}$ and the SAM INR21700-50E has $1579 \mathrm{~m} \Omega \cdot \mathrm{g}$ and $69.1 \mathrm{mAh} / \mathrm{g}$, for $1 \mathrm{C}$ pulse and $1 \mathrm{C}$ discharge both at $25^{\circ} \mathrm{C}$. So, among the cells tested in this investigation, 18650 type cells are better suited for applications requiring higher power, while the 21700 type cells are better suited for higher energy applications. This finding is supported by the observations in [17]. For some cells the values show small dispersion for all test cases, while others show wide variations both in temperature and in C-rate. As manufacturers use comparable main active materials, this arises most likely from other components like additives, separators and electrolytes. These variations allow trimming the battery for specific operating points or optimizing for some application modes.

The thermal tests, as expected, are correlated with the results of the impedance measurement. SAM INR21700-50E has a low overall impedance, and thus shows both low $\zeta_{\text {loss }}$ and low integral of HGR (Fig. 5). It is to be expected that the results are also transferable to 18650 cells.

For aging, no clear picture can be drawn. As cells were tested out of there operational window, some decayed very quickly while others could withstand these harsh conditions (see Fig. 6). As stated before, DOD $100 \%$ with $1 \mathrm{C}$ charge and discharge leads to the quickest decay. It must be noted, that for cycle life and performance evaluation, especially when considering the electrode design of the single cells, anode overhang and overcapacity should be considered as well [18]. Firstly, the physical overhang of the anode needs to be considered for winding/stacking of electrodes, in case of 18650 and 21700 this is usually an additional 0.3 and $0.5 \mathrm{~mm}$, respectively with additional overhang coming from the winding process over the mandrel. Secondly, over capacity of the anode needs to be considered when properly analyzing the effects of cycle life under fast charging profiles. Typically, the negative to positive ratio (N/P) should be 1.1 in terms of areal capacity. For fast charging protocols, a larger $\mathrm{N} / \mathrm{P}$ ratio of 1.2 to 1.25 can be beneficial. This has not been analyzed for each cell within this study in detail, because it was considered as an optimization factor for high energy vs. high power applications, whereas this study aimed to be broader in scope. The OEM profiles led to varying results. Five cells showed more than 600 cycles for the OEM1 profile. Considering this profile includes only fast charging, these numbers are acceptable. The OEM2 profile, which includes a vast share of high-power driving, does lead to a cycle life of 500 cycles and much less. For high performance cycles like this one, the higher values are still tolerable, while the lower ones would not be enough for real application.

\section{Conclusions}

Three 18650 and five 21700 cylindrical high energy cell types available on the market at the beginning of 2018 were purchased and tested in detail for their suitability for automotive applications. It is evident, that the main source for LIB cells is Asia. The manufacturers follow the strategy of driving down costs by reducing cobalt, applying Ni-rich cathodes. On the anode, G still is dominant, in five cases doped with small amounts of Si. 18650 and 21700 cells were found to vary in terms of suitable areas of application, the former are better suited for power, the latter better suited for energy applications. Despite this, no indications of 18650 compared to the new 21700 being the old or outdated form factor could be found. Both have weak and good performers in terms of electrical and cycle life performance and for the materials used, no indication of a drawback was identified. For an automotive application, most of the cells are only suited if no fast charging with high C-rates is applied. Cells with lower energy density and higher C-rates, which were not tested in this work, can be preferable if they offer better lifetime for such harsh automotive criteria.

\section{Acknowledgements}

The iModBatt project has received funding from the European Union's Horizon 2020 Programme for research and innovation under Grant Agreement No. 770054. 
The authors want to express their appreciation to Mr. H. J. Kapeller and Dr. I. de Meatza for the scientific discussions and their comments on earlier versions of the manuscript, and to Mrs. J. Winter and Mr. B. Ganev for correction and polishing of the language.

Publisher's Note Springer Nature remains neutral with regard to jurisdictional claims in published maps and institutional affiliations.

Open Access Dieser Artikel wird unter der Creative Commons Namensnennung 4.0 International Lizenz veröffentlicht, welche die Nutzung, Vervielfältigung, Bearbeitung, Verbreitung und Wiedergabe in jeglichem Medium und Format erlaubt, sofern Sie den/die ursprünglichen Autor(en) und die Quelle ordnungsgemäß nennen, einen Link zur Creative Commons Lizenz beifügen und angeben, ob Änderungen vorgenommen wurden. Die in diesem Artikel enthaltenen Bilder und sonstiges Drittmaterial unterliegen ebenfalls der genannten Creative Commons Lizenz, sofern sich aus der Abbildungslegende nichts anderes ergibt. Sofern das betreffende Material nicht unter der genannten Creative Commons Lizenz steht und die betreffende Handlung nicht nach gesetzlichen Vorschriften erlaubt ist, ist für die oben aufgeführten Weiterverwendungen des Materials die Einwilligung des jeweiligen Rechteinhabers einzuholen. Weitere Details zur Lizenz entnehmen Sie bitte der Lizenzinformation auf http://creativecommons.org/licenses/by/4.0/deed.de.

\section{References}

1. European Commission (2018): 2030 Climate \& energy framework. [Online] Available at: https://ec.europa.eu/clima/policies/strategies/2030_en.

2. European Environment Agency, 2019. Greenhouse gas emissions from transport in Europe. [Online] Available at: https://www.eea.europa.eu/.

3. International Energy Agency (2019): Global EV outlook. [Online] Available at: https://www.iea.org/reports/global-ev-outlook-2019.

4. Schröder, R., Aydemir, M., Seliger, G. (2017): Comparatively assessing different shapes of lithium-ion battery cells. Proc. Manuf., 8, 104-111.
5. Evoke Motorcycles, (2020): Evoke ultra-fast charging batteries. [Online] Available at: http://www.evokemotorcycles.com/batteries

6. Tesla, I. (2010): Battery pack and method for protecting batteries. US, Patent No. US7671565B2.

7. iModBatt Consortium (2020): Industrial modular battery pack concept addressing high energy density, environmental friendliness, flexibility and cost efficiency for automotive applications. [Online] Available at: https://cidetec.es/imodbatt/en/.

8. IEC (2018): IEC 62660-1:2018 - Secondary lithium-ion cells for the propulsion of electric road vehicles - Part 1: Performance testing. Switzerland: TC21.

9. Käbitz , S. (2016): In Untersuchung der Alterung von Lithium-Ionen-Batterien mittels Elektroanalytik und elektrochemischer Impedanzspektroskopie, Germany: RWTH Aachen.

10. Cendoya, I. (2018): Selection of commercial cells to fit a multiple purpose modular battery pack concept: iModBatt. London: International EV Batteries. 2018

11. Park, M., et al. (2010): A review of conduction phenomena in Li-ion batteries. J. Power Sources, 24(195), 7904-7929.

12. Zuo, X., Zhu, J., Müller-Buschbaum, P., Cheng, Y.-J. (2017): Silicon based lithium-ion battery anodes: a chronicle perspective review. Nano Energy, 31, 113-143.

13. Pillot, C. (2020): In The rechargeable battery market: value chain and main trends 2018-2028, Wiesbaden, AABC Europe.

14. Popp, H., et al. (2019): Benchmark, ageing and Ante-Mortem of SOTA CCylindrical lithium-ion cells. In 14th international A3PS conference on eco-mobility 2019, Wien.

15. Han, X., Ouyang, M., Lu, L., Li, J. (2014): A comparative study of commercial lithium ion battery cycle life in electric vehicle: capacity loss estimation. J. Power Sources, 268, 658-669.

16. Beatty, D., et al. (2019): Cobalt criticality and availability in the wake of increased electric vehicle demand: a short-term scenario analysis. Germany: Springer.

17. Quinn, J. B., et al. (2018): Energy density of cylindrical Li-ion cells: a comparison of Commercial 18650 to the 21700 cells. J. Electrochem. Soc., 14(165), A3284-A3291.

18. Lewerenz, M., Sauer, D. U. (2018): Evaluation of cyclic aging tests of prismatic automotive LiNiMnCoO2-graphite cells considering influence of homogeneity and anode overhang. J. Energy Stor., 18, 421-434.

\section{Authors}

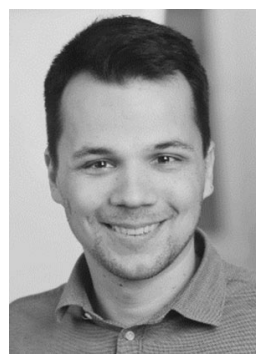

\section{Hartmut Popp}

received a MSc degree in industrial electronics from FH Technikum Vienna, Austria, and in environment and bioresources management from the BOKU University Vienna, Austria. Since 2017, he has been working toward a $\mathrm{PhD}$ degree at the Institute of Electrical Measurement and Sensor Systems, Graz University of Technology, Austria. After working as a Design Engineer at Siemens AG, he joined the AIT Austrian Institute of Technology. His research focus is on advanced diagnostic methods for Lithium-lon batteries. He is a student member of IEEE and OVE and part of IEC/OVE TC21 working group.

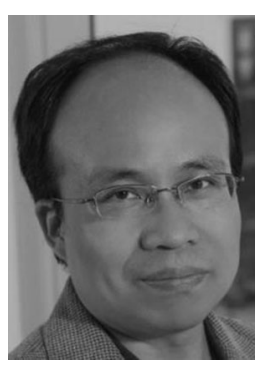

\section{Ningxin Zhang}

received his PhD from the Materials Science and Engineering department at Tsinghua University, Beijing, P.R. China. He has worked at Amperex Technology Limited, the supplier of Apple products for three years. Since October 2013, he has shifted his focus from industries to scientific research, focusing on the development of advanced processes for slurry and electrode preparation at AIT. His current topic is all-solid-state lithium-ion batteries. Dr. Zhang has published nearly 40 articles in peer- reviewed journals, and has filed seven patent applications on mixing equipment, electrode design, characterization and solutions to anode swelling.

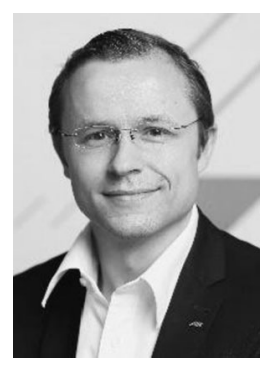

\section{Marcus Jahn}

received his PhD from the University of Nottingham, United Kingdom, on thin film Li-lon batteries. He has since worked at WMG, University of Warwick (UK), on a Pilot Lithium-Ion Battery cell manufacturing line since 2014. He has carried out several industrial projects as well as research projects financed by the UK and EU. He has therefore been part of a team that has brought WMG's LIB research from the start to its current widely known reputation within Europe. Dr. Jahn is currently a Senior Research Engineer at the AIT, where is the thematic lead for their battery team and has established AIT's research pilot line for pouch cell manufacturing.

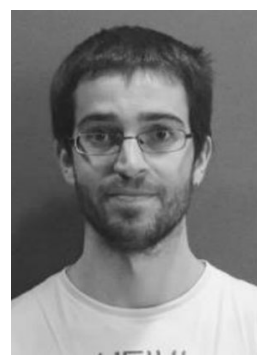

\section{Mikel Arrinda}

received the B.S. degree in industrial electronic engineering in 2012 at MU, Mondragon, Basque Country, Spain. In 2013 completed his studies with a M.S. in integration of renewable energy sources into the electricity grid at EHU, Bilbao, Basque Country, Spain. After three years of activity in a private company, in 2017, he started his current research as a Research Scientist at CIDETEC institute for Energy Storage. His research is focused on applying various regression and state estimation techniques for predicting remaining useful life of energy storage systems based on lithium ion batteries, as well as developing a controllable and user-friendly software for sizing of energy storage systems in terms of remaining useful life. 


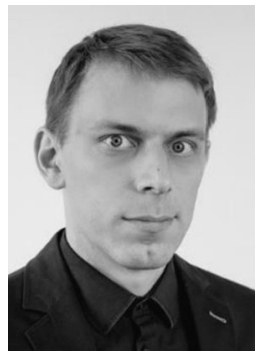

\section{Simon Ritz}

received his diploma in physics from RWTH Aachen University. Since then he works as a scientist in the department of Battery System Design and Vehicle Integration at the Chair of Electrochemical Energy Conversion and Storage Systems at the Institute for Power Electronics and Electrical Drives, RWTH Aachen University and is pursuing his Ph.D. degree. His research interests are battery testing, thermal battery characterization and parameterization methods and thermal management strategies.

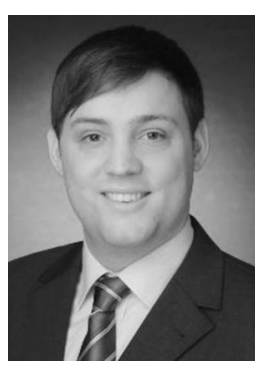

\section{Matthias Faber}

received the M.Sc. degree in chemical and process engineering from Karlsruhe Institute for Technology (KIT), Karlsruhe, Germany, in 2015. He is currently pursuing a PhD degree as a member of the Chair for Chemical Energy Conversion and Storage Systems at the Institute for Power Electronics and Electrical Drives, RWTH Aachen University, Aachen, Germany. His field of work includes analyzing the ageing effect of heterogeneous temperature distribution on the aging behavior of Lithium-ion batteries as well as their thermal parameterization and modelling.

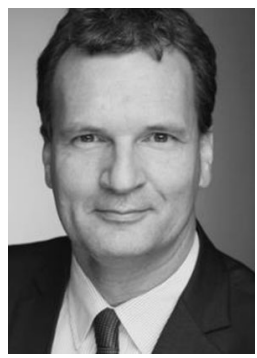

\section{Dirk Uwe Sauer}

currently holds the title of professor for electrochemical energy conversion and storage systems at the Institute for Power Electronics and Electrical Drives (ISEA) \& Institute for Power Generation and Storage Systems (PGS) at E.ON ERC RWTH Aachen University as well as Principle Investigator at Helmholtz Institute Munster Ionics in Energy Storage (part of Research Center Julich). Originally, professor Sauer studied physics at University of Darmstadt, Germany, and upon graduating in 1994 became a scientist, project coordinator and head of group at Fraunhofer Institute for Solar Energy Systems ISE in Freiburg until 2003 in the field of for storage systems, offgrid and remote power supply- systems. In 2003, he was appointed as junior professor at RWTH Aachen University, in 2009 he was ap- pointed as professor, and in 2012 he was appointed as full professor for electrochemical energy conversion and storage systems at RWTH Aachen University. Since 2010, he was a co-founder of 4 spin-off companies in the field of battery testing, battery diagnostics, or electrified public transport. Together with Prof. Martin Winter he is chairman of the conference "Kraftwerk Batterie / Advanced Battery Power". His research focus is on storage systems in electric vehicles of any kind, energy storage in grids with a high penetration of renewable energies, post-mortem analysis, ageing and lifetime prediction of batteries, modelling and diagnostics for batteries, and energy system analysis including sector coupling.

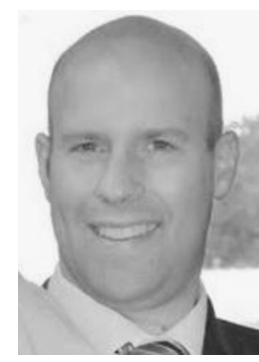

\section{Philippe Azais}

obtained his PhD degree in Sciences and Industrial Technologies in 2003 from the University of Orleans (France). He is Scientific Advisor \& Coordinator of program dedicated to electrochemical energy storage system at CEA-Liten. He has an extensive experience in carbon materials, energy storage systems and program management and is senior expert in the fields of supercapacitors, Li-ion batteries, post lithium-ion batteries and carbon materials.

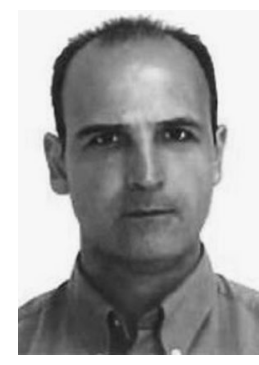

\section{losu Cendoya}

received his degree of Industrial Engineer at the School of Engineering of San Sebastian, (TECNUN), specialized in Electronics (2001). During 2001-2006, he worked for CEIT-TECNUN as a Researcher in the field of passive integrated circuits. Since 2006 until 2011, he joined the industry and developed his activity as Project Technical Manager in INDAR Electric, focused on the design and manufacturing of wind generators. In 2011 he started his current job, as Project Manager in the Systems Engineering Unit of CIDETEC Energy Storage. His current activity is focused on European projects management, especially in the field of battery pack development for automotive applications. He is the coordinator of the H2O2O iModBatt project and partner in the Hi-Fi Elements and COBRA H2O2O projects. 